\title{
Analysis of Human-Wildlife Conflict in Buffer Zone Area: A Case Study of Shuklaphanta National Park, Nepal
}

\author{
Maheshwari Bhatta ${ }^{1}$, Rajeev Joshi*2 \\ ${ }^{1}$ Division Forest Office, Kanchanpur-10400, Nepal. Email: mahi6608@ gmail.com \\ ${ }^{2}$ Amity Global Education (Lord Buddha College), CTEVT, Tokha-11, Kathmandu-44600, Nepal \\ *Corresponding author: joshi.rajeev20@gmail.com | ORCID: 0000-0003-1106-9911
}

How to cite this paper: Bhatta, $M$. and Joshi, R. (2020). Analysis of HumanWildlife Conflict in Buffer Zone: A Case Study of Shuklaphanta National Park, Nepal. Grassroots Journal of Natural Resources, 3(3): 28-45. Doi:

https://doi.org/10.33002/nr2581.6853.03033

Received: 16 June 2020

Reviewed: 10 July 2020

Provisionally Accepted: 15 July 2020

Revised: 21 August 2020

Finally Accepted: 31 August 2020

Published: 15 September 2020

Copyright (C) 2020 by author(s)

This work is licensed under the Creative Commons Attribution International License (CC BY 4.0). http://creativecommons.org/licenses/by/4.0/
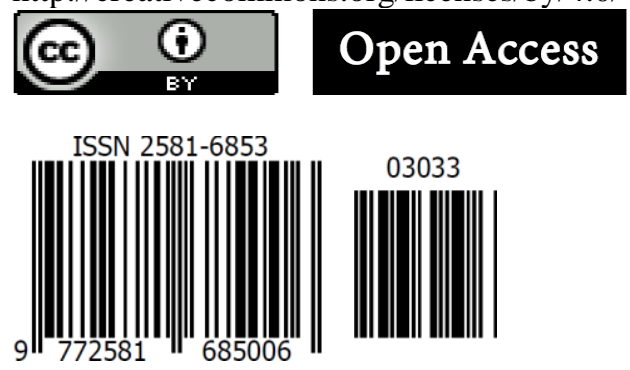

\begin{abstract}
This article is based on a study carried out in buffer zone of Shuklaphanta National Park (SNP), which lies in Kanchanpur district of Nepal. It is aimed to assess nature and extent of crop damages, livestock depredation and human casualties, and to identify local people's attitude towards wildlife conservation and management. Primary data was collected through preliminary field visit, questionnaire survey of households, key informant interviews, focus group discussion and direct field observation. Paddy was major crop damaged by wild animals, followed by wheat and maize. Wild boar followed by elephant and deer were found as the most problematic animals causing crop damage, while common leopard was found as the major culprit for livestock depredation. The proximity to the national park was found determining factor to the extent of damage caused by the wild animals. People's attitude towards wildlife conservation was found to be positive; however, more than $85 \%$ of respondents showed dissatisfaction towards park authorities' effort for conflict management. Active participation of local people in conservation and awareness program can play a vital role to reduce and mitigate the human wildlife conflict at community level.
\end{abstract}

Keywords

Buffer zone, Crop damage, Compensation, Habitat, Human-Wildlife Conflict 
Doi: https://doi.org/10.33002/nr2581.6853.03033

\section{Introduction}

Today, the world is facing massive loss of biodiversity and the extinction of number of species. To overcome the challenges of conserving existing species, protected areas (PAs) have been critical to conserve biodiversity (Lopoukhine, 2008). In the places having no social safety nets, humans tend to exert increasing pressure on ecosystem services and resources, and these resulting additional pressures can damage ecosystems to the point of no return (Hassan et al., 2005).

Human-wildlife conflict (HWC) is defined as: "any interaction between humans and wildlife that results in negative impacts on human's social, economic or cultural life, on conservation of wildlife populations, or on the environment" (WWF, 2005). HWC is a common phenomenon for long past and has become a significant problem throughout the world (Wang and Macdonald, 2005). Crop raiding, property damage, livestock depredation and human casualties are the most common causes of conflicts with wildlife (Ogra and Badola, 2008). Establishment of protected areas (PAs) network has been main strategy for long-term protection of biodiversity in Nepal, since the beginning of 1970s (HMG/N, 2002). The expansion of PAs has, however, come into direct conflict with traditional linkages and immediate needs of local livelihoods that depend upon forest resources for their survival (Silwal et al., 2013). Many researchers have found that human wildlife conflicts are more serious in such sub-optimal habitats (Acharya et al., 2016). Besides, wild animals moving out from the parks damage agricultural crops, livestock and properties and frequently cause human injury or death. Wildlife damages as a direct result of wildlife are often quoted resentment of local people and retaliatory killings of even endangered species (Silwal, 2003; Banikoi et al., 2017).

Shuklaphanta National Park (SNP) is surrounded by human settlements and agricultural land where conflict between human and wildlife is the problematic issue. There is close interface between forest and rural people in Nepal; over $95 \%$ of population of Nepal directly depends on forest for firewood, timbers and NTFPs (Gautam, 2006). Many of the park areas are surrounded by agricultural lands. The people living in and around such national parks have interacted with parks in multiple ways. Some of them have created an ecological and harmonious relationship with the national park, whereas in certain areas the existence of the national park has been questioned because of the growing conflict over land use rights and practices (Nepal and Weber, 1993). Wildlife attacks on humans are becoming one of the major hindering factors for maintaining harmonious relationships with local people and mobilizing them in conservation. Various studies reported that the poor communities are relatively more dependent on forest resources, which increase the complexity of protected area management for both human and wildlife needs (Budhathoki, 2004; Rayamajhi, 2010). Without properly addressing HWC, efforts to conserve wildlife and their habitats will lose stability and progress, as well as the support of local communities (Madden, 2004). Such information about HWC can provide essential guidance for establishing future conservation, management and research priorities in Nepal (Primack et al., 2013).

From the conservation point of view, increased number of wildlife within protected areas shows success of conservation. However, some animals like elephant, tiger, rhino, wild boar, leopard and blue bull (Nilgai) often make losses to the peoples living in the vicinity of protected areas, and Shuklaphanta National Park is not an exception. The conflicts, which result from the destruction of crops and damage to property, are serious conservation issues both inside and 
outside the Park. Many studies have been undertaken in different protected areas of Nepal on HWC; but not sufficient studies related to such conflict issues are conducted in Shuklaphanta National Park. Therefore, it is urgent to assess the human wildlife conflict in Shuklaphanta National Park for better understanding about the local people's role and their perception on wildlife conservation. This article provides insights into the existing scenario of human wildlife conflicts in Shuklaphanta National Park and suggests conservation and management strategies to mitigate human wildlife conflict. Thus, research is designed to assess the conflict between conservation of Shuklaphanta National Park and people residing in fringe areas of the park, in the buffer zone. The specific objective of this study is to predict and identify the degree of HWC such as crop damage, livestock depredation and human loss, and to identify and understand the perceptions and attitude of local communities towards wildlife conservation and management.

\section{Materials and Methods}

\section{Study area}

The study was carried out in buffer zone of Shuklaphanta National Park (SNP) which lies in Bhimdatta Municipality (Ward no. 15 and 19) of Kanchanpur district in the Far Western Province of Nepal (Figure 1). The buffer zone with an area of $243.5 \mathrm{~km}^{2}$ was notified in May 2004. The buffer zone is extended into 5 urban municipalities namely Bedkot, Belauri, Bhimdatta, Mahakali, Shuklaphanta and 2 rural municipalities (Beldandi and Laljhadi). At the initial period, area of SNP was famous as hunting ground and was declared as a Royal Hunting Reserve in 1969 followed by the notification as Shuklaphanta Wildlife Reserve covering $155 \mathrm{~km}^{2}$ in 1976 . Later, it was extended to the north-east section up to Syali river with an additional area forming total area of $305 \mathrm{~km}^{2}$ in 1981, and recently its status is transformed as national park w.e.f. $20^{\text {th }}$ February 2017. SNP lies at the geographical location of longitude $80^{\circ} 25^{\prime \prime}$ E and latitude $28^{\circ} 35^{\prime \prime}$ N. Its altitudinal range varies from 90 masl to 270 masl. The headquarters of the park is located at Majhgaon of Bhimdatta Municipality.

SNP is the only protected area which has been set up exclusively to conserve world's endangered largest herd of swamp deer, which makes it as a globally important site for conservation of endangered species. It is also home to wildlife species protected under Convention on International Trade in Endangered Species of Wild Fauna and Flora (CITES), such as the Royal Bengal tiger, Indian leopard, elephant, sloth bear and Hispid hare. In fact, it is the largest refuge of already endangered Bengal florican.

\section{Sampling design}

After taking information about the wards of Bhimdatta Municipality within buffer zone of SNP, depending upon most conflict prone areas two wards were selected randomly, i.e. ward number 15 (Gobariya) and 19 (Baghfata). The selection criteria were based upon the information regarding the crop damage, livestock damage and human casualties obtained from key informants (DFO, SNP office, BZMC and local leaders). Sampling used for this study was purposive sampling with sampling intensity of $5 \%$. Both quantitative and qualitative approaches were used to extract reliable data. The primary data were collected from the study site by employing combination of social survey methods involving participatory techniques such as on-site field observation, household survey questionnaire $(n=80)$, key informant interview, and focus group 
discussions (FGDs). These methods were applied to extract the information such as socioeconomic conditions, major conflicting animals, crop loss, major season of conflict, local techniques to mitigate the human-wildlife conflict, perceptions and attitude of local people towards effectiveness of present techniques, and local people's ideas on HWC mitigation, wildlife conservation and management. The necessary secondary data were collected from Shuklaphanta National Park (SNP) office, Buffer Zone Management Committee (BZMC) office, National Trust for Nature Conservation (NTNC) and Institute of Forestry (IOF) library. Besides, various related websites were surfed.

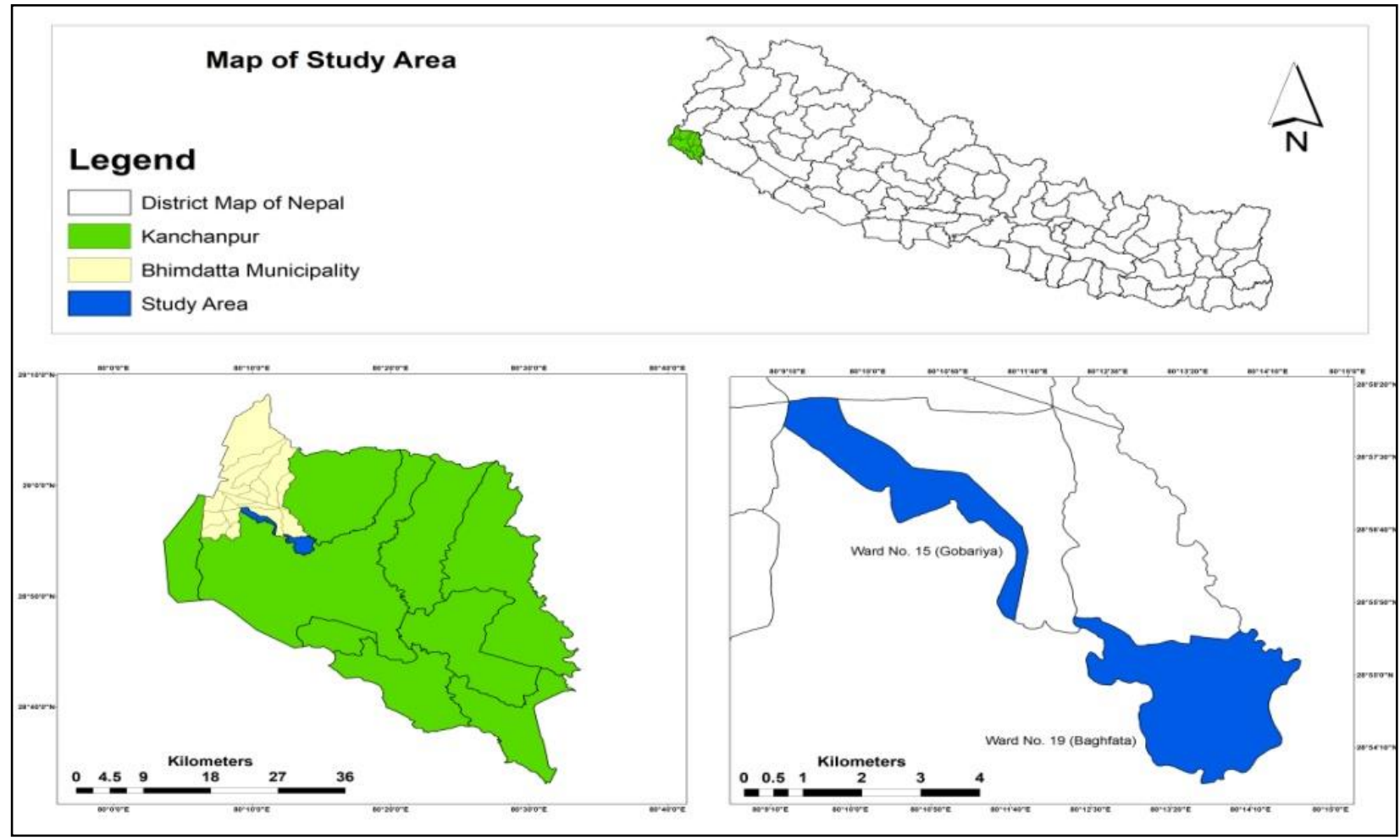

Figure 1: Map of the study area

\section{Sample size}

The list of different households of each ward was taken from BZMC. The total number of households (HHs) inside buffer zone of SNP in ward no. 15 (Gobariya) and ward no. 19 (Baghfata) were 816 and 817, respectively. Over 40 households were taken from each ward on the basis of total households residing inside buffer zone of SNP. Altogether 80 household were selected and interviewed. To determine the sample size (n) for the questionnaire household survey, the following formulae given by Arkin and Colton (1963) was used at 95\% confidence interval.

Where,

$$
\text { Sample size }(\mathrm{n})=\frac{\mathrm{N} \times Z^{2} \times P(1-P)}{\mathrm{N} \times d^{2}+Z^{2} \times P(1-P)}
$$

$\mathrm{N}=$ total number of households

$\mathrm{Z}=$ value of standard variant at $95 \%$ confidence level (1.96) 
$\mathrm{P}=$ estimated population proportion $(0.05)$

$\mathrm{d}=$ error limit of $5 \%(0.05)$

Similarly,

$$
\text { Average damage per year per HHs }(\mathrm{Kg})=\frac{\text { Total damage of crops of sampled HHs }}{\text { Number of sampled HHs }}
$$

Total damage of crops of sampled HHs $(\mathrm{Kg})=$ Sum of total damage of crops of each sampled HHs

Monetary economic value of crops per year per HHs (NRs.) = Average damage per year per HHs $(\mathrm{Kg}) \times$ Local market value of each crops per $\mathrm{kg}$

\section{Data analysis}

The collected qualitative and quantitative data were analyzed by using statistical tools through MS-Excel program and later exported to Statistical Package for Social Sciences (SPSS) for further analysis. The results were organized and presented in tables and various chart types. All the data collected were checked, refined and scrutinized as per the objectives and further results were interpreted by descriptive frequencies such as mean (average and arithmetic mean), percentage and count (minimum and maximum).

\section{Results}

\section{Socio-Economic Characteristics of Respondents}

Out of the 80 respondents, 40 from each ward were questioned during the study. More than $20 \%$ of respondents were women in both wards. The proportion of male to female respondents was still higher in both wards $(72.50 \%$ males and $27.50 \%$ females in ward no. 15 or Gobariya and $77.50 \%$ males and $22.50 \%$ females in ward no. 19 on Baghfata) (Figure 2). However, to minimize the gender bias, the survey was based on the availability of the household members during the field study.

The household survey interview was conducted with respondents aged between 18 to 60 years to obtain reliable information. About $63 \%$ of the respondents had the age exceeding 40 years in ward no.15 (Gobariya), whereas in ward no.19 (Baghfata), more than $67 \%$ of the respondents were in the age group of $>40$ years. It shows that the information collected in both the wards was mostly from middle adulthood respondents (40-60 years). In both wards, there was less percentage of respondents with an age group <20 years (Figure 3 ).

About $90 \%$ of the respondents were literate and remaining $10 \%$ were illiterate in ward no.15 (Gobariya). Similarly, more than $82 \%$ of the respondents of ward no.19 (Baghfata) were literate and remaining $17.50 \%$ were illiterate (Figure 4 ). 


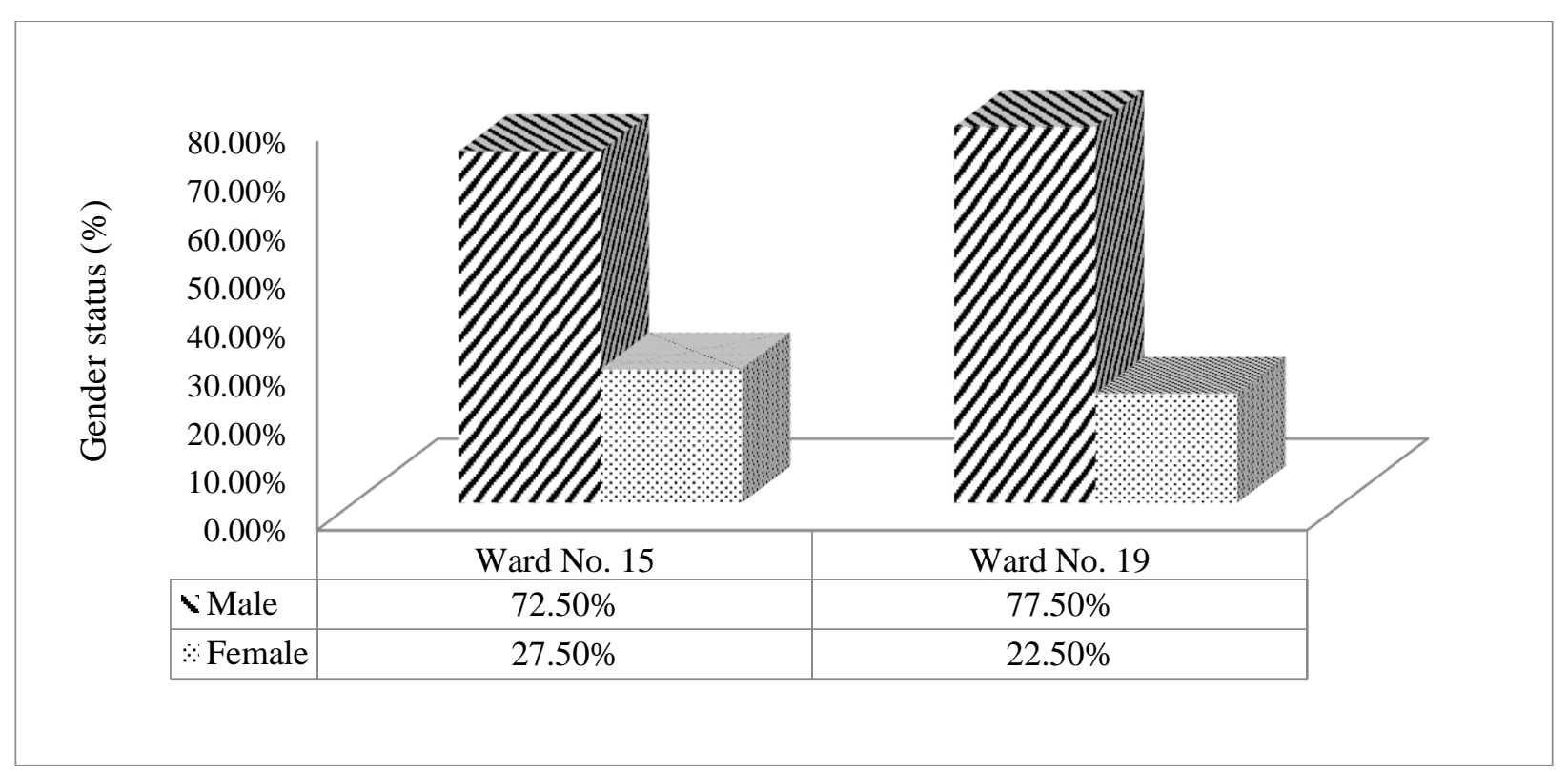

Figure 2: Proportion of male to female respondents

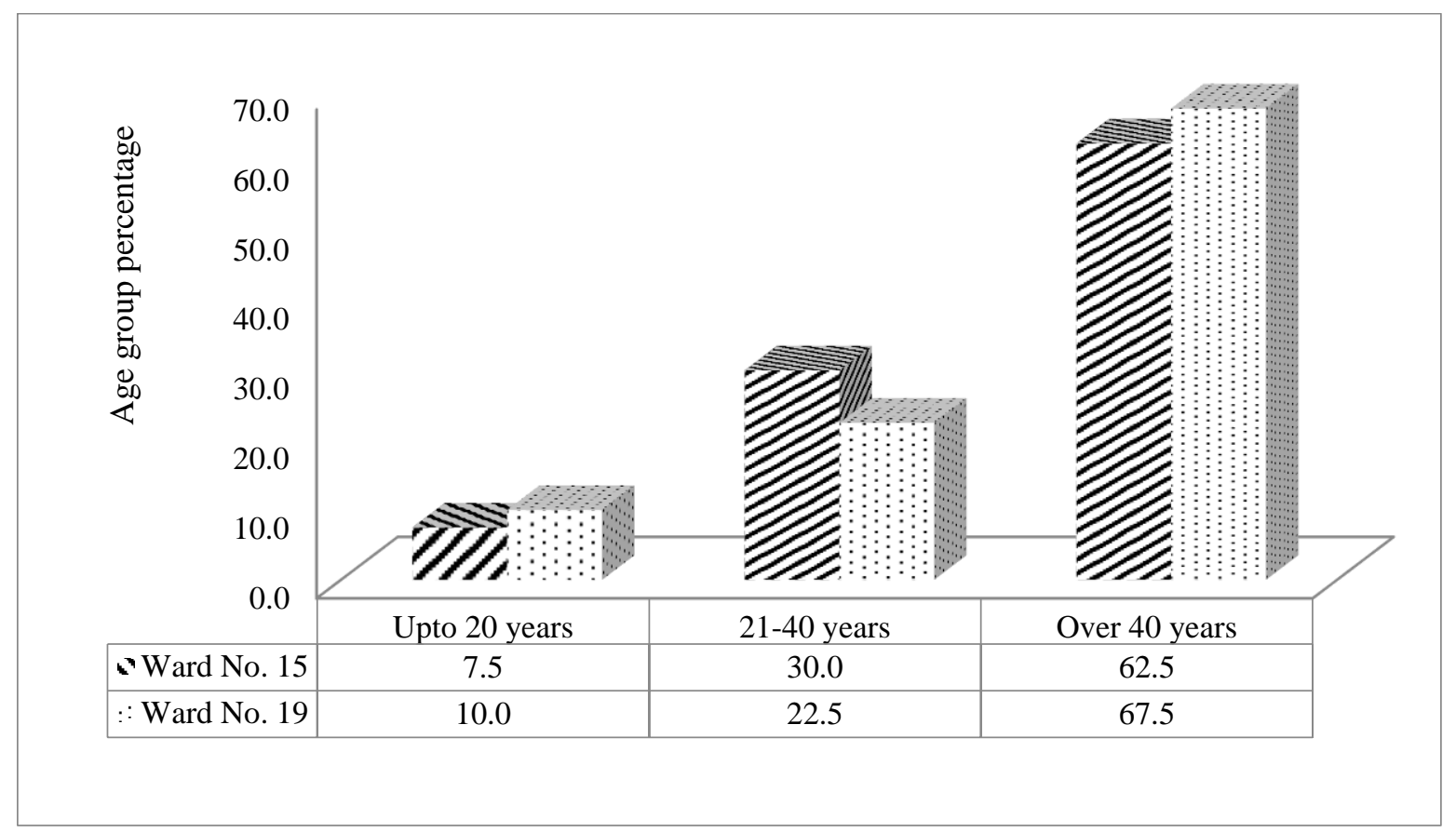

Figure 3: Age group status of the respondents of both Wards

\section{Nature and extent of crop damage, livestock depredation and human casualties}

Altogether 80 respondents, 40 from each ward, were surveyed to know their views regarding the awareness level and also to measure their perceptions towards wildlife conservation. Massive damage of agricultural crops was found as one of the most prominent effects of human-wildlife conflict in the study area. The nature and extent of crop damage, livestock depredation and human casualties as suggested by the respondents are illustrated in the following sections: 
Doi: https://doi.org/10.33002/nr2581.6853.03033

\subsection{Major problem animals of conflicts}

Respondents reported the problematic animals with prioritization as per the severity of damages caused by those animals (Figure 5). The damages are classified into two categories: crop damages and livestock depredation. Here, $68.75 \%$ of the respondents in the study area have prioritized wild boar as the most problematic crop damaging animal, and $85 \%$ of the respondents have prioritized leopard as the most problematic livestock damaging animal.

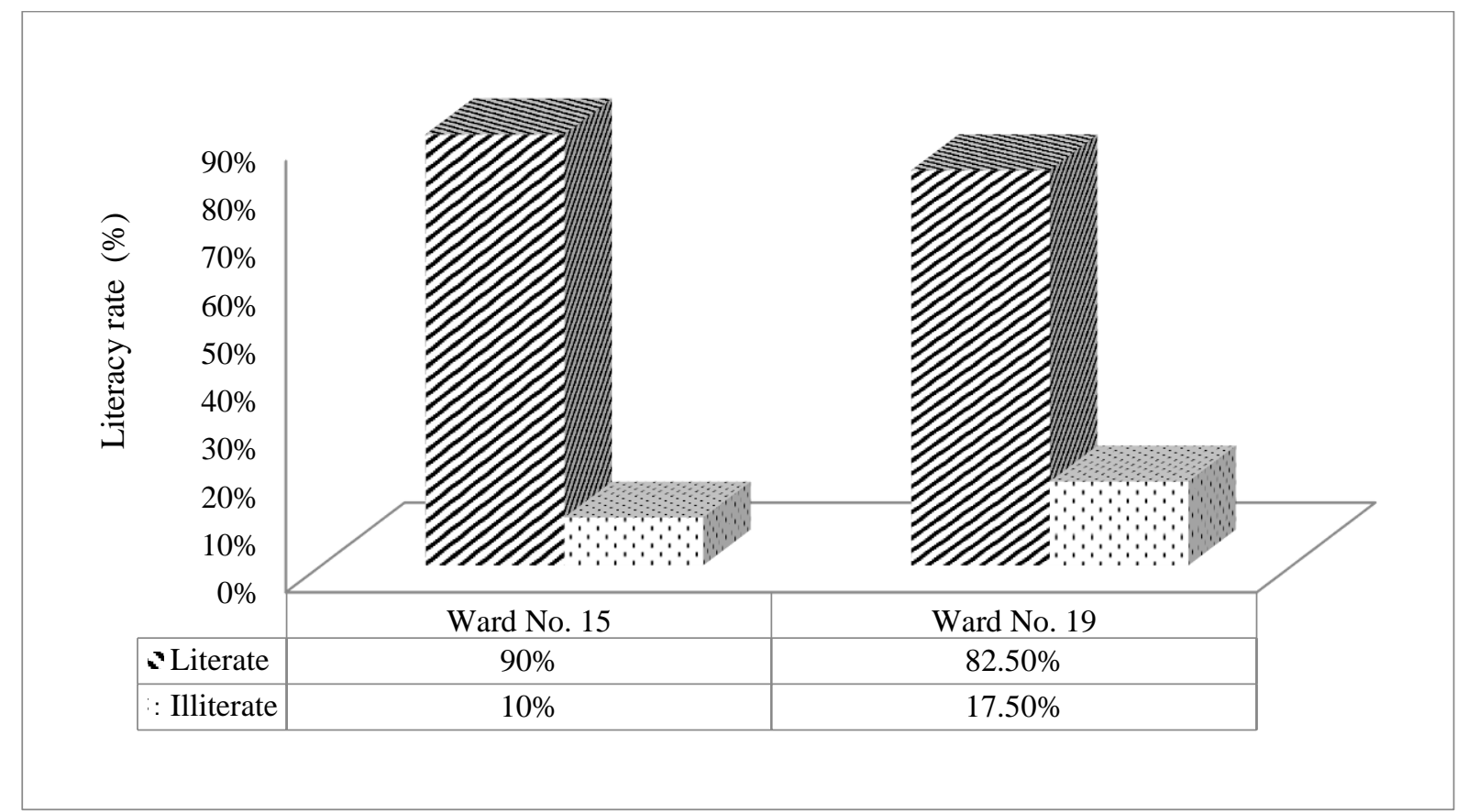

Figure 4: Literacy rate of respondents of both the wards

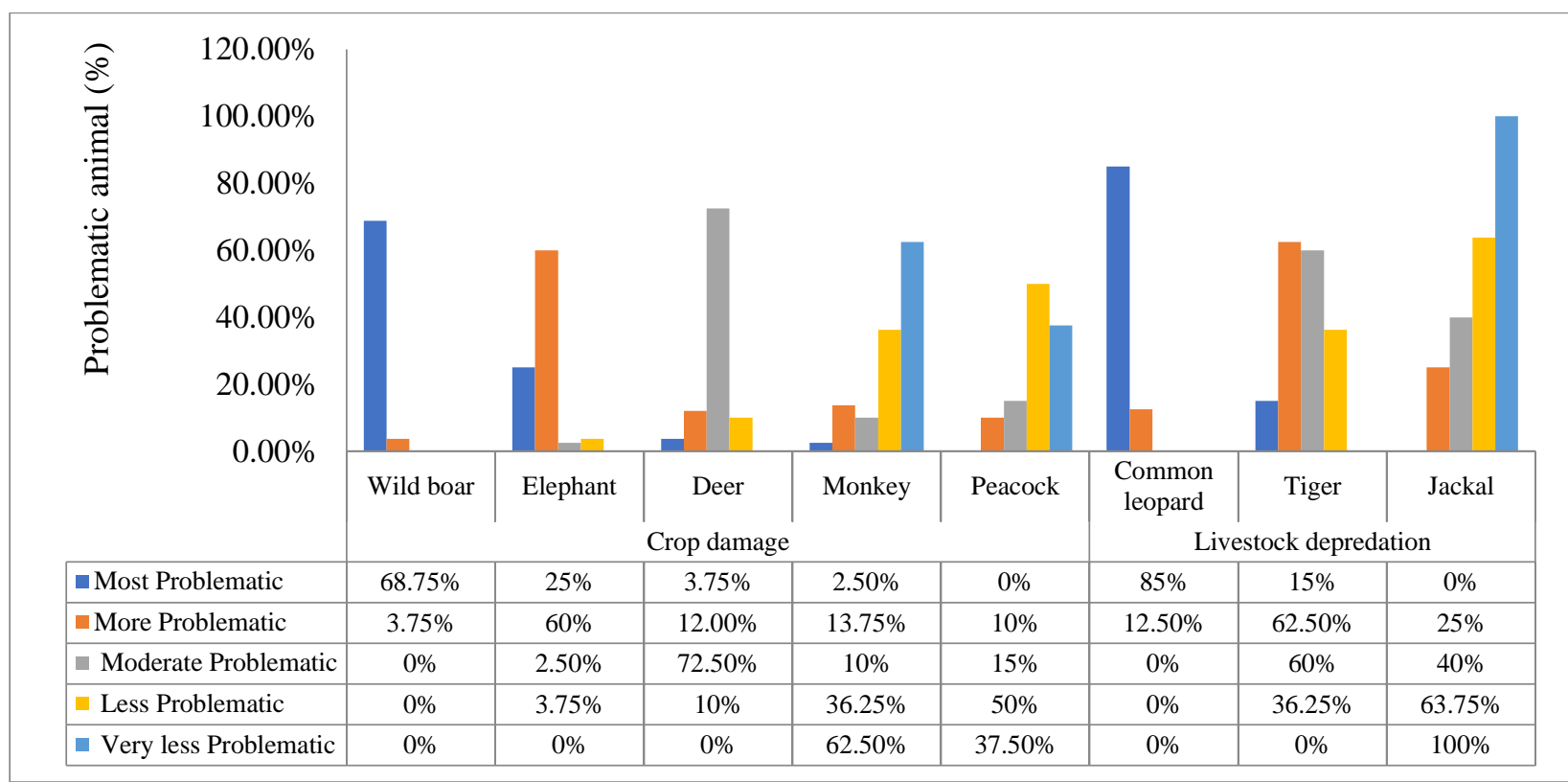

Figure 5: Prioritizing problematic animals by respondents in percentage (\%) 


\subsection{Frequency of wildlife damage}

Different species have its own movement behavior. Availability of food inside the park determines the movement of wildlife and its frequency moving outside the park. Wild boar and deer were the most frequently visiting wild animals into the crop land. While leopard comes out seasonally, tiger and elephant come out rarely (Figure 6). The incursion of wild animals in the crop land was found high during night hours, though wild animals like elephant, hare, monkey and deer damaged crops in the day time also.

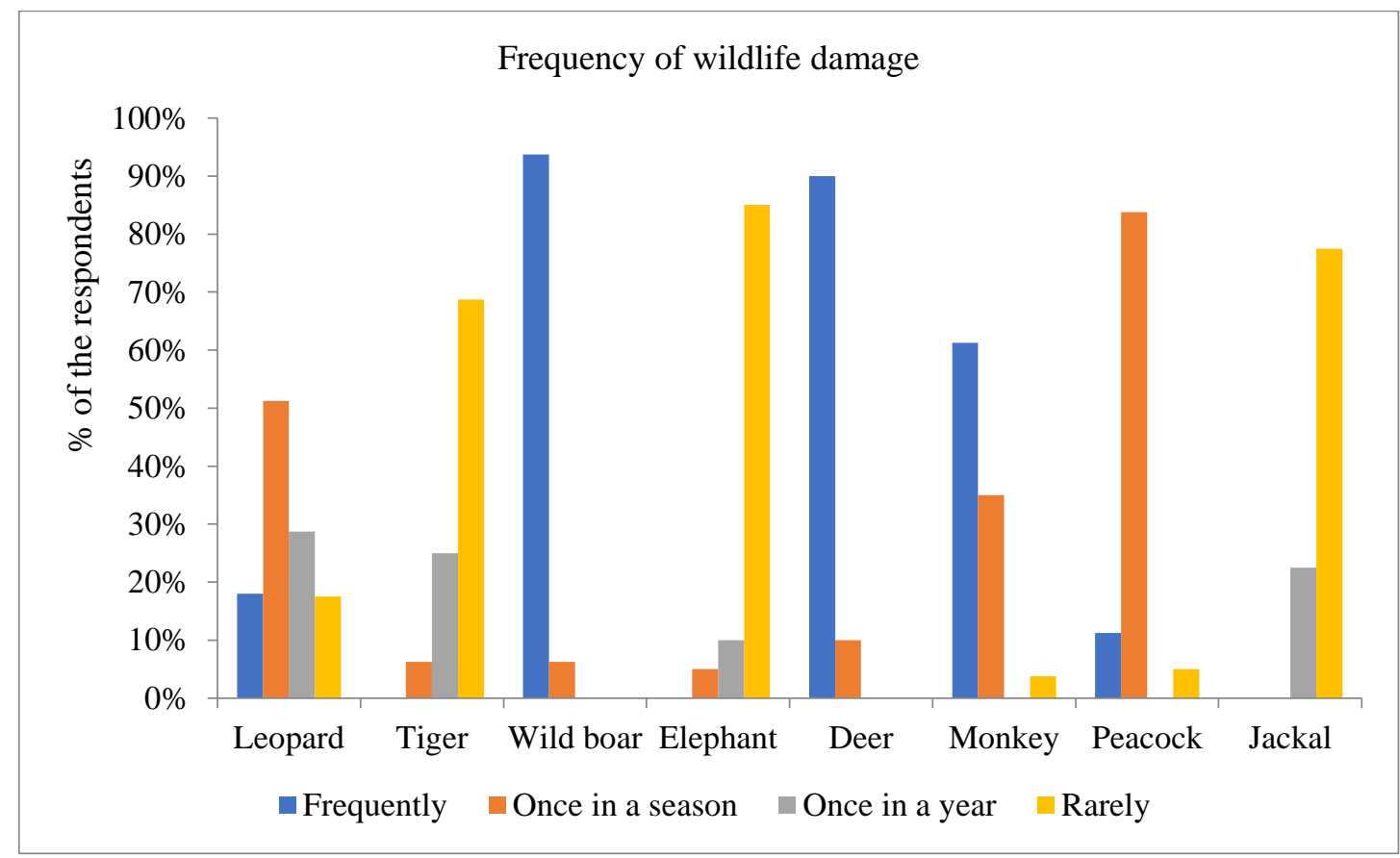

Figure 6: Problem animal showing their frequency of visit in the study sites

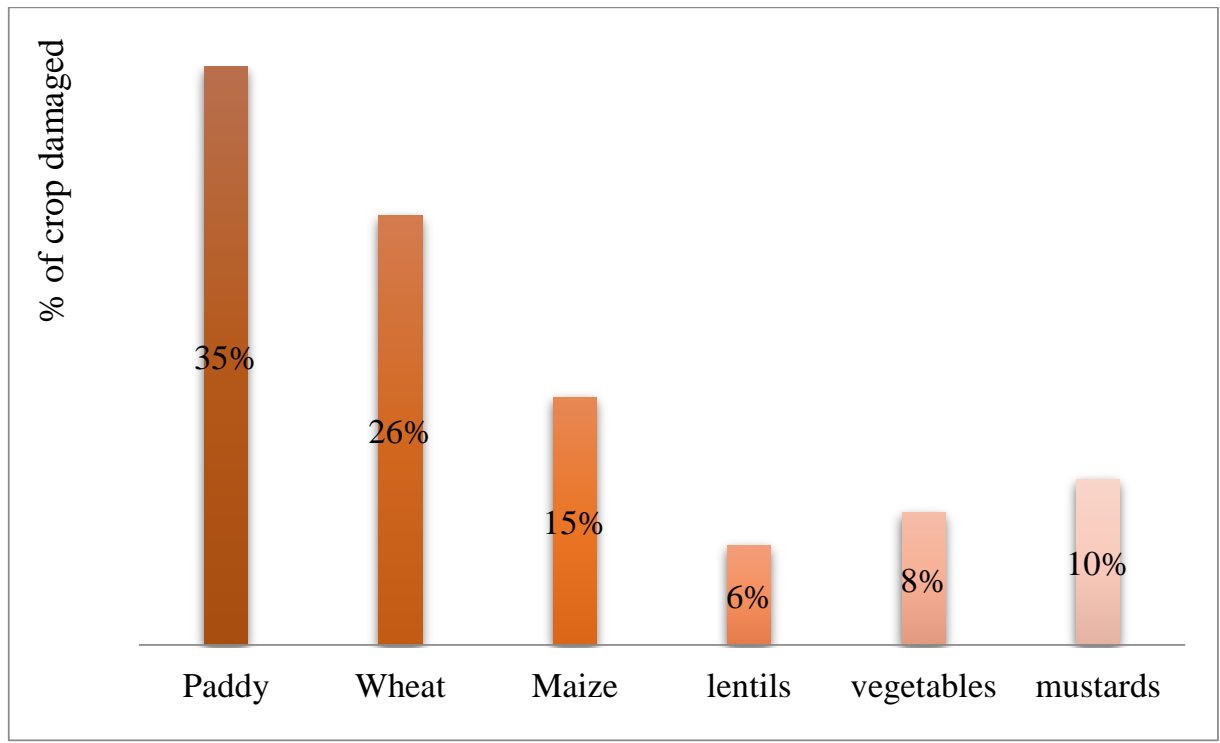

Figure 7: Crops damaged in the study area 


\subsection{Major crops damaged}

Paddy, maize and wheat are major agricultural crops that get damaged in the study area. $35 \%$ of respondents responded in favor of paddy as the major damaged crops. 26\% and 15\% of total respondents, respectively, opted wheat and maize as next most damaged crops in the study area. Lentils, vegetable crops and mustard were comparatively lesser damaged crops (Figure 7).

\subsection{Major causes of conflict}

Most of the respondents believed that food scarcity in their habitat is the main cause for wild animal to visit outside their habitat area (Figure 8).

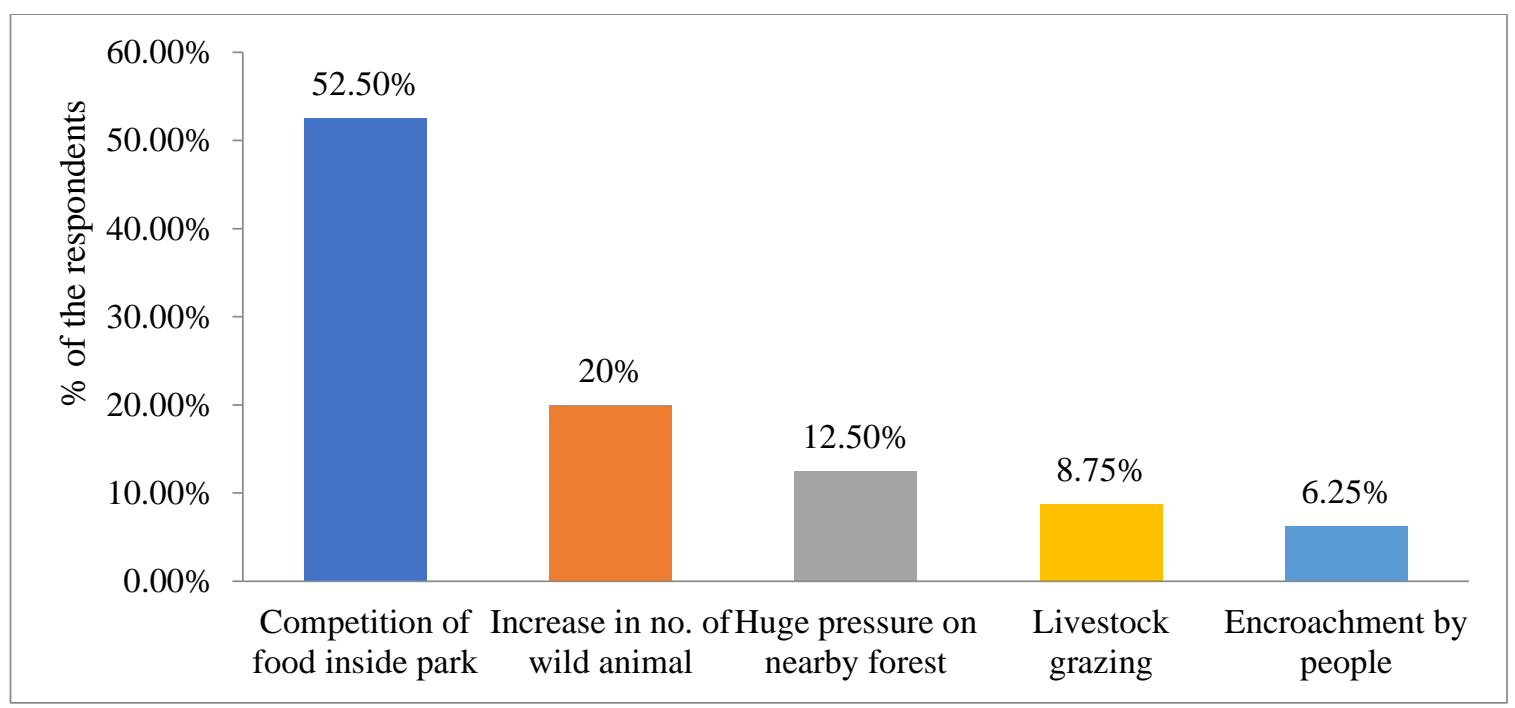

Figure 8: Major causes of conflict

\subsection{Households affected by the crop damage}

Though the wildlife e.g. wild boar, elephants, swamp deer, monkey, peacock and hare were mostly involved in crop depredation, effect of wild boar, elephant and deer was found voluminous. Following table shows that $52.5 \%$ of respondents suffered crop depredation of $<2$ quintal/season, and $33.75 \%$ of respondents showed crop depredation of $2-5$ quintals/season (Table 1).

Table 1: Quantities of crop depredation of HHs in each ward

\begin{tabular}{|c|c|c|c|c|}
\hline \multirow{2}{*}{$\begin{array}{c}\text { Quantity in } \\
\text { quintals/season }\end{array}$} & \multicolumn{2}{|c|}{ No. of respondent in each ward } & \multirow{2}{*}{ Total } & $\begin{array}{c}\text { Percentage } \\
\text { response (\%) }\end{array}$ \\
\cline { 2 - 3 } & Ward No. 15 & Ward No. 19 & & $52.50 \%$ \\
\hline$<2$ & 22 & 20 & 27 & $33.75 \%$ \\
\hline $2-5$ & 12 & 15 & 6 & $7.50 \%$ \\
\hline $6-10$ & 3 & 3 & 5 & $6.25 \%$ \\
\hline$>10$ & 3 & 2 & 80 & $100 \%$ \\
\hline Total & 40 & 40 & & 42 \\
\hline
\end{tabular}




\subsection{People's response towards leaving land barren due to wildlife problem}

Despite having wildlife conflict and crop damage, the respondents of both the wards do not leave their land uncultivated, which is mainly due to poverty and insecurity of food.

\subsection{Applying various techniques to prevent crop damage from wild animals}

About $60 \%$ of respondents were not using any sort of technique for defying the wild animals. Remaining $40 \%$ of respondents used chasing as an effective method followed by the fencing, scarecrow, and electric fencing. Fencing of crop land, using scarecrow and machan guarding were found to be common techniques used to prevent damage from wild animals. Among them use of fence was intensively used by many respondents, and it was followed by scarecrow and machan guarding.

\subsection{Status of livestock depredation}

In the study area, only $12.5 \%$ and $27.5 \%$ of the respondents, respectively, of ward no. 15 and ward no. 19 responded that their domesticated animals had been killed by wild animals during the last 5 years (Figure 9).

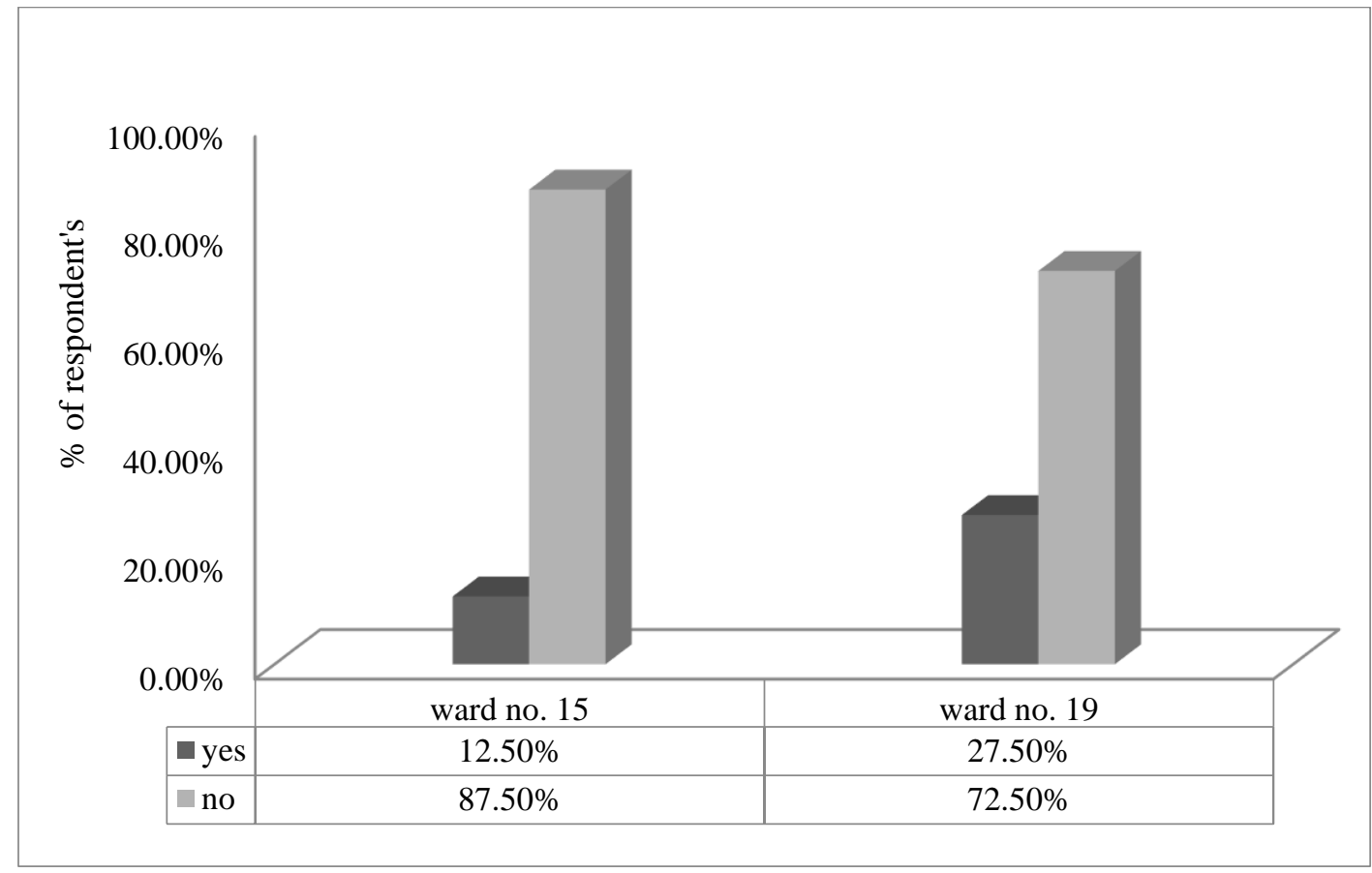

Figure 9: People's response on wild animals attacking livestock

\subsection{Depredation of livestock in last five years}

The depredation of livestock was found in very low magnitude during last 5 years. Altogether 16 domestic animals were killed in the study area; among which 11 were killed in ward no. 19 and 5 were killed in ward no. 15 (Figure 10). Most of the animals were killed inside the national park. According to the respondents, total 9 domestic animals were killed inside the park in ward no. 19 
Doi: https://doi.org/10.33002/nr2581.6853.03033

(Baghfata) and 2 domestic animals were killed in ward no. 15 (Gobariya).

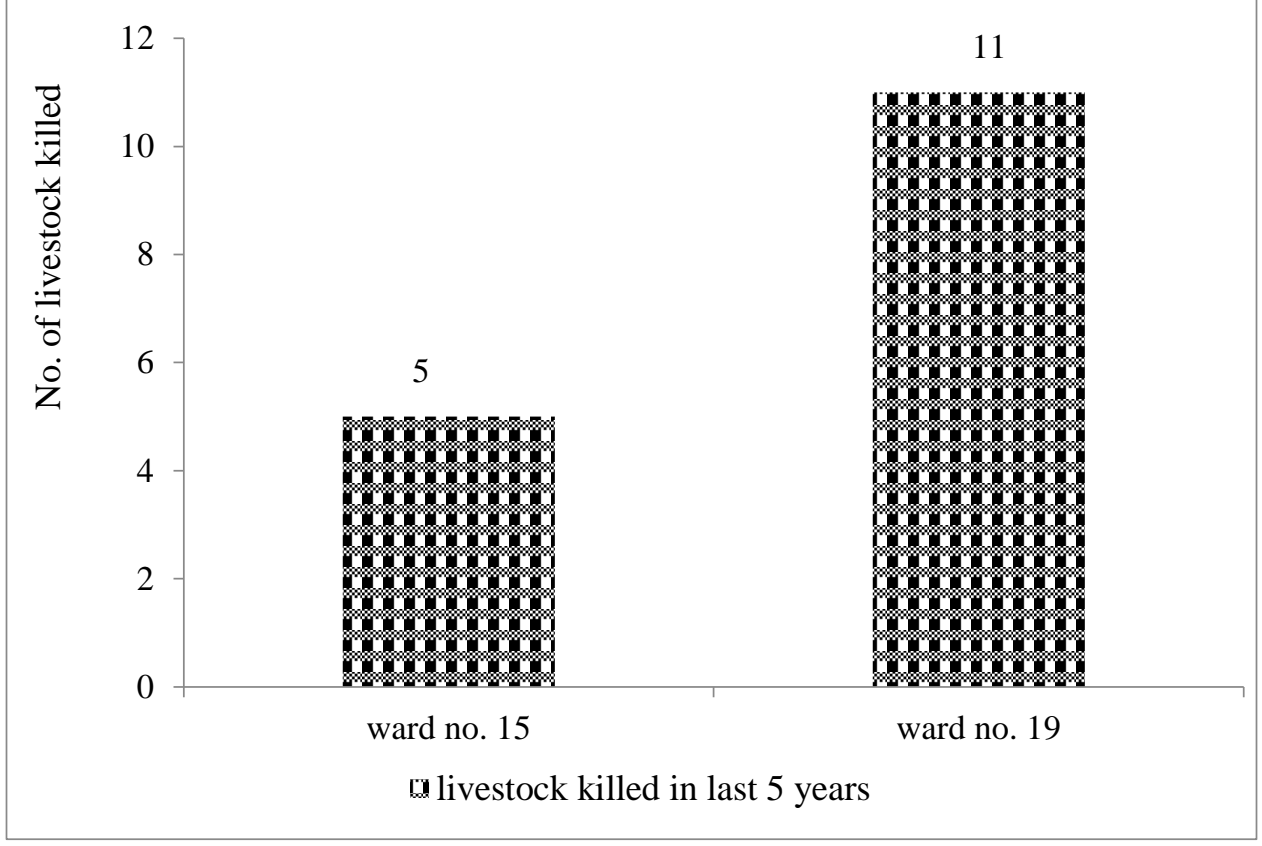

Figure 10: Status of livestock killed during 5year period

\subsection{Trend of livestock depredation}

Most of the respondents of both wards said that the trend of livestock depredation has been decreasing (Figure 11). It is probably due to abundance of ungulates inside the park.

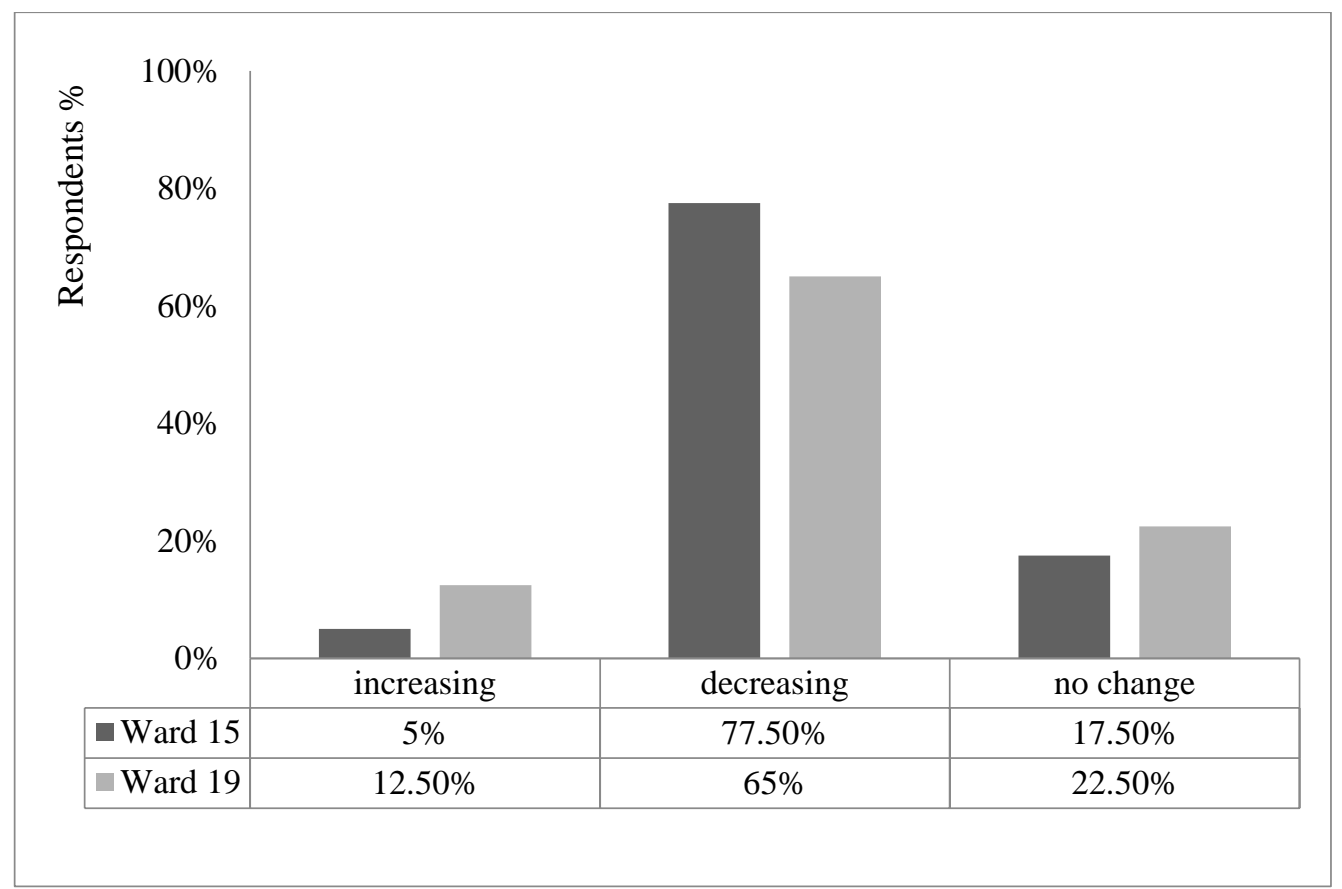

Figure 11: Trend of livestock depredation 
Doi: https://doi.org/10.33002/nr2581.6853.03033

\subsection{Wildlife responsible for livestock depredation}

It was found that common leopard was most responsible for the depredation of livestock in the study area which was followed by tiger. Out of total 16 livestock killed in last five years, 10 were killed by common leopard and 6 by tiger.

\subsection{Human casualties}

There was only one case of human casualty in last five years which was in ward no. 19 in 2014 and wild animal responsible for this incidence was elephant. Therefore, human casualties were insignificant in the study area.

\subsection{Estimated monetary value of property damage by wild animals}

Property damage was another salient issue occurring due to the HWC in the study area. In selected two wards, the average estimated monetary loss per household was higher in ward no. 19 than in ward no. 15. The average loss in monetary term per household was NRs. 6002.22 per year in ward no. 19 (Baghfata) and NRs. 3186.32 per year in ward no. 15 (Gobariya) (Figure 12). It was because of higher damage rate of crop, livestock and property in ward no. 19 than ward no. 15. Wild boar and common leopard were the major contributors of monetary loss in the study area.

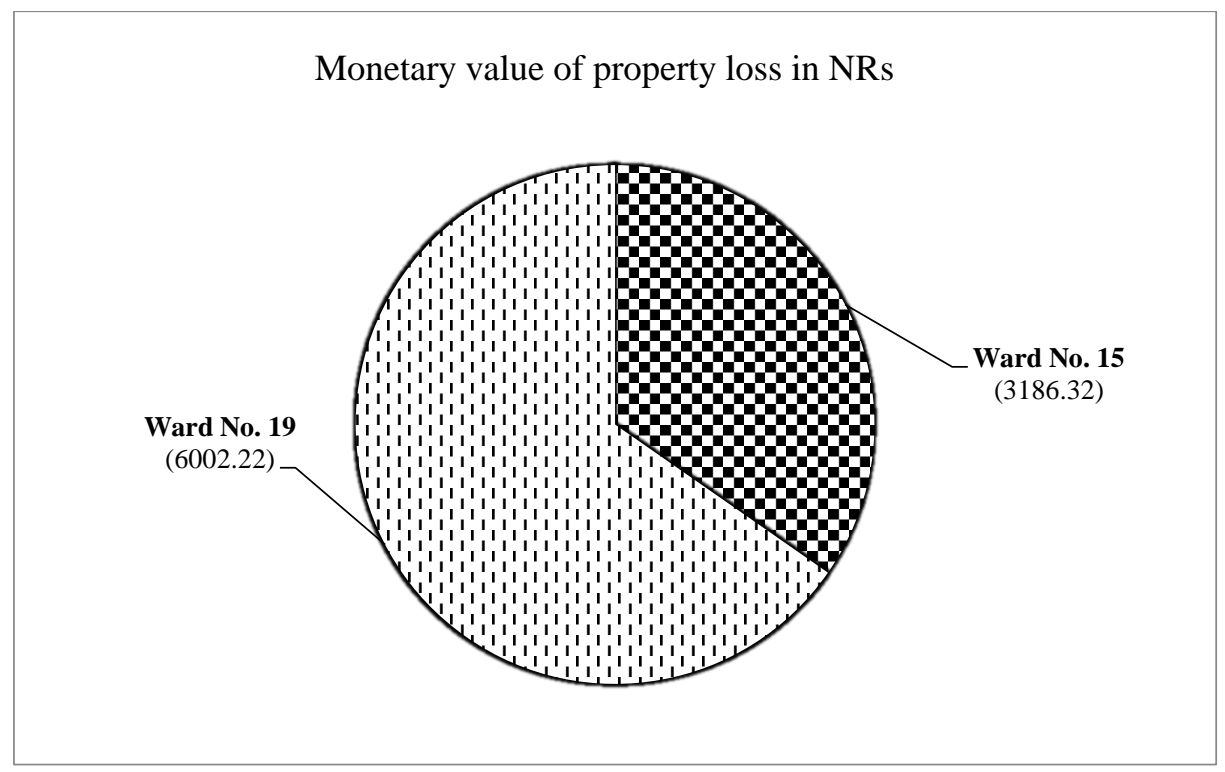

Figure 12: Average estimated monetary value of property damage by wild animals (NRs)

\subsection{Comparison of types of conflicts}

The intensity of crop damages was usually greater in the study area. About $65 \%$ of the respondents had suffered from damages of crops only. $20 \%$ of the respondents faced the livestock depredation only, while $13.75 \%$ of the respondents had faced both the livestock depredation and crop damages. Nearly, $1.25 \%$ of respondents had experienced crop damages, livestock depredation as well as human casualties (Figure 13). 


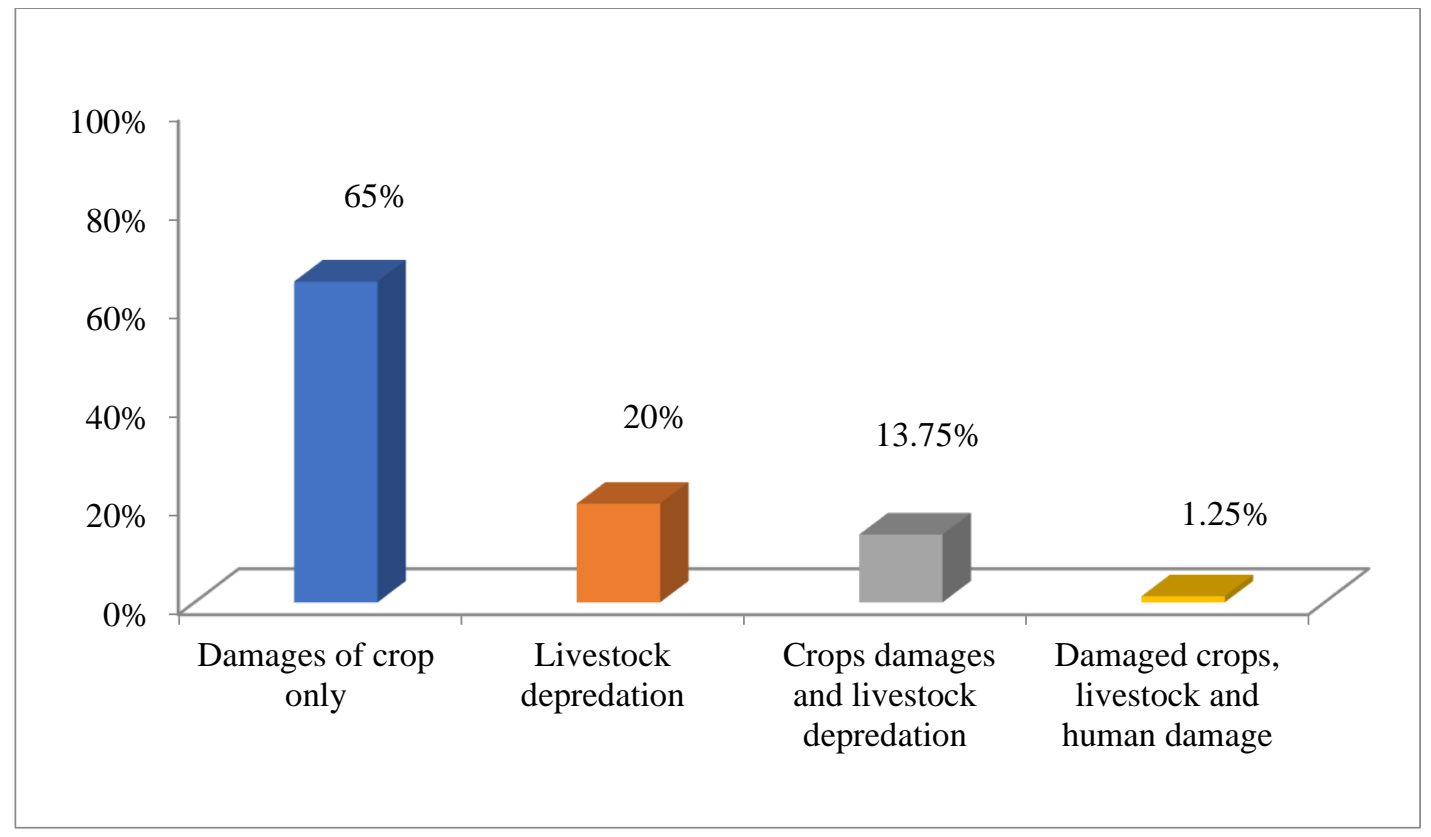

Figure 13: Comparison of types of conflicts

\section{People's Perception towards Wildlife Conservation}

\subsection{Necessity of conservation}

While all the respondents of ward no. 15 (Gobariya) and no. 19 (Baghfata) were asked to show their perception on the statement "it is necessary to conserve wild animals in the National Park", $71.25 \%$ of total respondents agreed on the statement that wildlife should be conserved, while few $(22.5 \%)$ were neutral towards the statement due to lack of knowledge about wildlife and only least number of respondents $(6.25 \%)$ showed disagreement towards the wildlife conservation (Table 2). It was observed that negative perception towards wildlife conservation was due to their illiteracy, lack of awareness and compensation policy. Respondents of ward no. 15 were found to be more positive towards wildlife conservation than respondents of ward no. 19 (Figure 14).

Table 2: People's response towards the necessity of wildlife conservation

\begin{tabular}{|c|c|c|c|c|}
\hline \multirow{2}{*}{ Ward/Village } & \multicolumn{2}{|c|}{ People perception towards wildlife conservation } & \multirow{2}{*}{ Total } \\
\cline { 2 - 4 } & Agree & Neutral & Disagree & \\
\hline 15 (Gobariya) & 30 & 9 & 1 & 40 \\
\hline 19 (Baghfata) & 27 & 9 & 4 & 40 \\
\hline Total & 57 & 18 & 5 & 80 \\
\hline Percentage (\%) & $71.25 \%$ & $22.50 \%$ & $6.25 \%$ & $100 \%$ \\
\hline
\end{tabular}




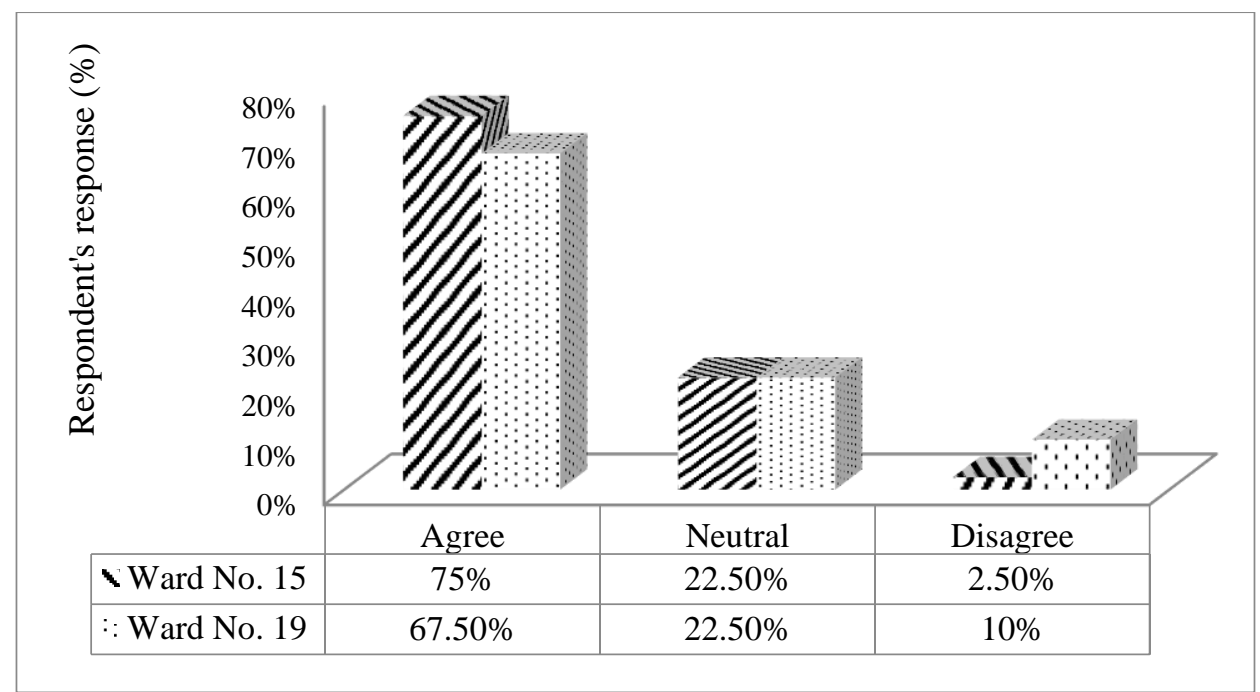

Figure 14: Response of respondents towards the necessity of wildlife conservation in both wards

The females were found more positive towards wildlife conservation due to their active involvement in awareness programs and women empowerment process. Literate respondents were found more positive than illiterate respondents and young respondents were more positive towards wildlife conservation.

\subsection{Importance of wildlife}

Out of total 80 respondents, about $13.75 \%$ answered that wildlife should be conserved because they are our national property and beauty to the nature (aesthetic value); $16.25 \%$ of them answered that they are important in balancing the nature (ecosystem value); $26.25 \%$ of them told that wildlife are important for educational purpose; $5 \%$ of the respondents opined that the wildlife should be conserved for religious value; $23.75 \%$ respondents told that the presence of wildlife helps to attract the domestic and international tourists contributing to revenue of the country (tourism value); and $15 \%$ of them did not see any benefits of conserving wildlife in the nature.

\subsection{Response towards park's effort towards conflict management}

Responses of the people show huge dissatisfaction towards the park administration's efforts for conflict management. $85 \%$ of respondents reported negative response towards solving HWC (Figure 16). They feel that park was established for the animals and they were free to do crop damages, livestock depredation or human casualty. On the contrary, the local residents are restricted seriously as they need pass to travel. Lack of proper compensation for damages and no effective conflict resolution techniques were implemented. 


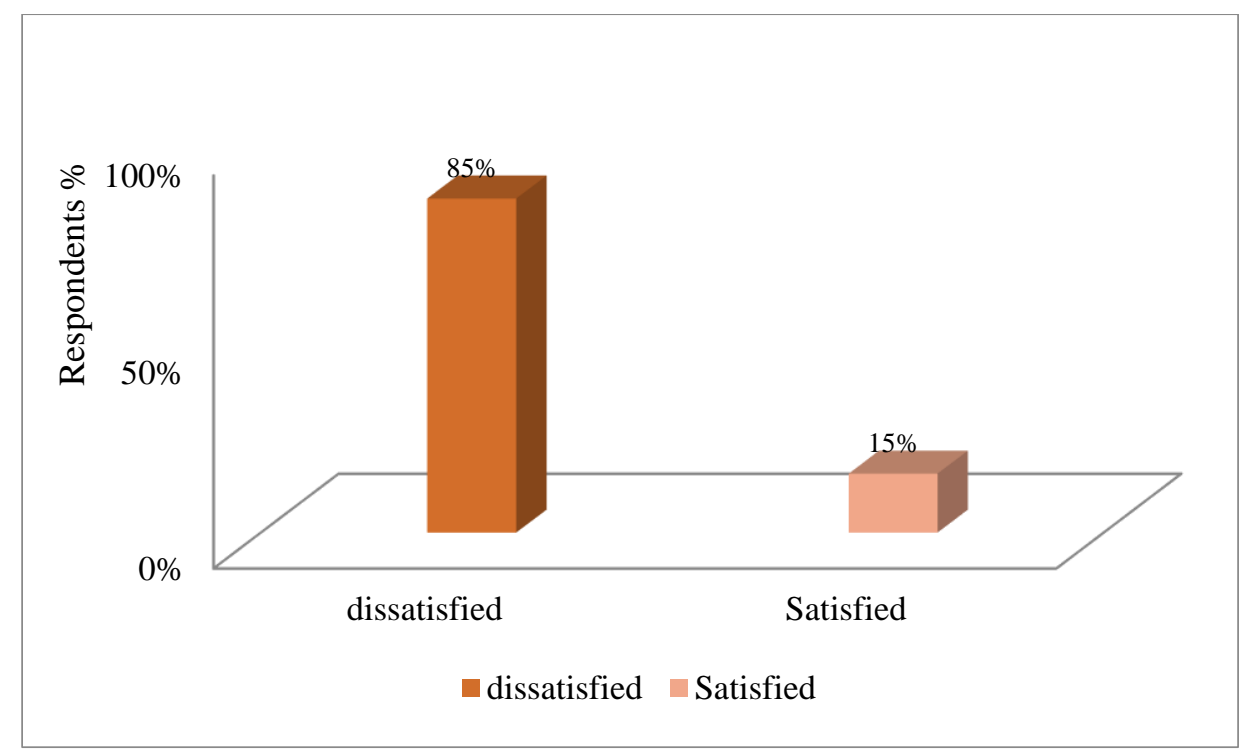

Figure 15: Response towards park's effort towards park management

\section{Discussion}

The ecological relationship between humans and wildlife is the most challenging and debating one. As both of them increasingly find themselves competing for space, a continual struggle for resources and their official conservation territory leads to human-wildlife conflict. Agriculture production is the main occupation of the respondents living in the vicinity of Shuklaphanta National Park. In the study area, the crop damage done by the wild animals of major crops was high. Among affected crops, paddy was the most damaged and affected crop. It may be due to its large-scale production, its high palatability and proteinous nature than any other crops grown in the study area. In Chitwan, Jhapa and Bardiya National Parks, the major crop (paddy) is highly affected and damaged by wild animals, and it accounted nearly 60-70\% of total economic loss (WWF, 2007; Ghimire, 2019).

It is found that average crop loss per season in monetary term is NRs. 3421.58 per year; however, previous research by Malla (2003) shows average loss per household due to crop damage was NRs. 962 per year. The reason behind that damage was more distance of study area from the forest. As the distance from national park increases, quantum of damage decreases, which shows that there is inverse relation between crop damage and the distance. Similarly, the average economic loss suffered by each household was of NRs. 10,108 per year in Bardiya (WWF, 2007) and NRs. 9211.4 per year in the Chitwan district (Ghimire, 2019). Different researchers have found that increase in number of wild animals, biotic pressure and food shortage was the major cause for rising HWC, which was supported by the study conducted by Shrestha (2007). Respondents living closer to national park territories tend to suffer more incidences and costs of crop losses as compared to people living far from national park boundaries (Mackenzie et al., 2012). Various studies have found that crop damage by wildlife often occurs at the peak availability of crops especially during the crop harvesting time (Warren et al., 2007).

A study carried out by Ayadi (2011) showed that local people were adopting the different techniques to protect croplands from wild animals. This study found that local people of study 
area were also adopting the different techniques to protect croplands from wild animals. From this study, it was found that the people around buffer zone of Shuklaphanta National Park were positive towards wildlife conservation, which was supported by WWF (2007). This was mainly because most respondents here generally accepted the conservation friendly ideas such as reducing disturbance to wildlife habitats. Based on the information collected from respondents, the total number of wild animals has increasing after the establishment of Shuklaphanta National park, which was found to be similar with other studies (Awasti and Singh, 2015; Pokharel and Shah, 2008). The local respondents reported that killing and poaching of wild animals were very common practices before the establishment of Shuklaphanta National Park. According to Hill (1997), people develop negative perceptions and attitude towards wildlife when damage caused by wildlife exceeds the limit of tolerance. Negative perceptions and the attitude towards wildlife could be the big challenge for conservation despite the heavy conservation efforts. When human casualties happen, local respondents start agitating against the conservation projects. Therefore, urgent need of appropriate solution for human-wildlife conflict must be recognized, and humanwildlife conflict should be treated as the most challenging and difficult issue for wildlife conservation and management. Hence, it is mandatory to draw appropriate strategies and measures to deal with all the losses and compensation measure is often considered as an essential tool to mitigate human-wildlife conflict.

\section{Conclusion}

The cases of human-wildlife conflicts are increasing in recent years. Residents of Shuklaphanta National Park identified four major problems and eight most problematic wild animals in two studied wards. Crop damage was the major problem faced by the local respondents of both wards. Damage of paddy crop was higher than other crops. The chances of conflict between human and herbivore wild animals were high; however, very few cases of human casualties were reported. Wild boar and deer, elephant and tiger, and leopard cause damage frequently, rarely and seasonally, respectively. The most problematic animals for livestock depredation were leopard, tiger and jackal, whereas highly problematic animals for crop damage were wild boar, elephant and deer. The average estimated monetary loss per household per year was higher in ward no. 19 (Baghfata) than ward no. 15 (Gobariya). It was believed that the most attacking animal was leopard followed by tiger. Similarly, crop land of ward no. 19 (Baghfata) was more damaged than crop land of ward no. 15 (Gobariya) and there was only one case of human casualty by wildlife during last five years. Most of the respondents were not using any type of technique to prevent entrance of wildlife animal in their crop land, except few were using fencing, scarecrow, machan guarding and combination of various techniques. People's attitude towards wildlife conservation was found to be positive. The perceived importance of wildlife conservation was significantly different. Most of the local people showed dissatisfaction towards the park authorities' efforts for conflict management. Female, literate and young respondents were more positive towards wildlife conservation in the study area. It concurs that most people of the study areas were aware about the wildlife conservation and management which denotes a good sign for the mitigation and reduction of the problem. It is recommended a systematic review of current implementation of buffer zone programs to understand existing problems and to design improved strategies and policies for compensation of crop damage and livestock depredation in order to change perception and attitude of local people towards wildlife. 
Doi: https://doi.org/10.33002/nr2581.6853.03033

\section{References}

Acharya, K.P., Paudel, P.K., Neupane, P.R. and Köhl, M. (2016). Human-wildlife conflicts in Nepal: patterns of human fatalities and injuries caused by large mammals. PLOS One, 11(9). Doi: http://doi.org/10.1371/journal.pone.0161717

Arkin, H. and Colton, R.R. (1963). Tables for Statisticians (2nd ed.). New York: Barnes and Noble Inc., pp 55.

Awasthi, B. and Singh, N. (2015). Status of Human-Wildlife Conflict and Assessment of Crop Damage by Wild Animals in Gaurishankar Conservation Area, Nepal. Journal of Institute of Science and Technology, 20(1), 107-111. Doi: https://doi.org/10.3126/jist.v20i1.13918

Ayadi, D.P. (2011). Human-Wildlife Conflict in Buffer Zone Area: A Study of Banke National Park, Nepal (Doctoral dissertation, Master Thesis, Environment Science of Tribhuvan University, College of Applied Sciences, Nepal).

Banikoi, H., Thapa, S., Bhattarai, N., Kandel, R.C., Chaudhary, S., Timalsina, N., Windhorst, K., Karky, B.S., Adhikari, M.D. and Pokheral, C.P. (2017). Mitigating human-wildlife conflict in Nepal: A case study of fences around Chitwan National Park. International Centre for Integrated Mountain Development (ICIMOD), Kathmandu, Nepal.

Budhathoki, P. (2004). Linking communities with conservation in developing countries: buffer zone management initiatives in Nepal. Oryx, 38(3): 334-341. Doi: https://doi.org/10.1017/S0030605304000584

Gautam, K.H. (2006). Forestry, politicians and power-perspectives from Nepal's forest policy. Forest Policy and Economics, 8(2): 175-182. Doi: https://doi.org/10.1016/j.forpol.2004.07.001

Ghimire, P. (2019). Analysis of Human Wildlife Conflict in Buffer Zone Area: A Study from Chitwan National Park, Nepal. International Journal of Natural Resource Ecology and Management. Special Issue: Forest and Wildlife Management, 4(6): 164-172. Doi: 10.11648/j.ijnrem.20190406.12

Hassan, R., Scholes, R. and Ash, N. (2005). Ecosystems and human well-being: current state and trends. Washington: Island Press.

Hill, C.M. (1997). Crop-raiding by wild vertebrates: the farmer's perspective in an agricultural community in western Uganda. International Journal of Pest Management, 43(1): 77-84.

HMG/N. (2002). Nepal Biodiversity Strategy Government of Nepal. Ministry of Forest and Soil Conservation (Global Environment Facility), UNDP, Kathmandu, HMG, Nepal.

Lopoukhine, N. (2008). A Global Perspective on the Challenges and Opportunities for Protected Areas in Today's and Tomorrow's World -"For Life's Sake". "Paper Commissioned for Canadian Parks for Tomorrow: $40^{\text {th }}$ Anniversary Conference. University of Calgary, AB".

Mackenzie, C.A. and Ahabyona, P. (2012). Elephants in the garden: Financial and social costs of crop raiding. Ecological Economics, 75: 72-82. Doi: 10.1016/j.ecolecon.2011.12.018

Madden, F. (2004). Creating coexistence between humans and wildlife: global perspectives on local efforts to address human-wildlife conflict. Human Dimensions of Wildlife, 9(4): 247257. Doi: https://doi.org/10.1080/10871200490505675

Malla, R. (2003). Park - people conflict: A case study from Beldandi VDC adjacent to SWR, Far Western lowland, Nepal. A project paper submitted for the fulfillment of the requirement for B.Sc. Forestry, Institute of Forestry, Tribhuvan University, Nepal.

Nepal, S.K. and Weber, K.E. (1993). Struggle for existence: park-people conflict in the Royal Chitwan National Park, Nepal. CAB International, Pp 17. ISBN: 9748209601.

Ogra, M. and Badola, R. (2008). Compensating human-wildlife conflict in protected area 
communities: ground-level perspectives from Uttarakhand, India. Human Ecology, 36(5): 717. Doi: https://doi.org/10.1007/s10745-008-9189-y

Pokhrel, G.K. and Shah, K.B. (2008). Role of community forests in faunal diversity conservation: a case study of community forests within Satbariya Range Post of Dang District. Nepal Journal of Science and Technology, 9: 111-117. Doi: https://doi.org/10.3126/njst.v9i0.3174

Primack, R.B., Paudel, P.K. and Bhattarai, B.P. (2013). Conservation biology: A primer for Nepal. Kathmandu, Nepal: Dreamland Publication.

Rayamajhi, S. (2009). Forest dependency, livelihoods and conservation of high altitude forests in Nepal (Doctoral dissertation, Forest \& Landscape, University of Copenhagen).

Shrestha, R.K. and Alavalapati, J.R.R. (2007). Linking Conservation and Development: An Analysis of Local People's Attitude Towards Koshi Tappu Wildlife Reserve, Nepal. J. Environment, Development and Sustainability, 8 (1): 69-84.

Silwal, T. (2003). Rural Livelihoods and Diversity in Buffer Zone. A Case Study from Royal Bardia National Park, Nepal. Institute of Forestry, Tribhuvan University, Nepal.

Silwal, T., Shrestha, B., Bhatta, B. and Devkota, B. (2013). Revenue distribution pattern and park-people conflict in Chitwan National Park, Nepal. Banko Janakari, 23(1): 35-41. Doi: https://doi.org/10.3126/banko.v23i1.9465

Wang, S.W. and Macdonald, D.W. (2006). Livestock predation by carnivores in Jigme Singye Wangchuck National Park, Bhutan. Biological Conservation, 129(4): 558-565. Doi: https://doi.org/10.1016/j.biocon.2005.11.024

Warren, Y., Buba, B. and Ross, C. (2007). Patterns of crop raiding by wild and domestic animals near Gashaka Gumti National Park, Nigeria. International Journal of Pest Management, 53(3): 207-216.

WWF (2005). Human wildlife conflict manual 2005: Wildlife management series. World Wide Fund for Nature, Southern African Regional Program Office (SARPO).

WWF (2007). A Case Study on Human-Wildlife Conflict in Nepal (With particular reference to Human-Elephant Conflict in Eastern and Western Terai regions)", World Wildlife Fund, Kathmandu, Nepal, pp. 47-48. 